\title{
Impact Of Nurse Unionization On Fiscal Viability And Selected Measures Of Quality In Hospitals
}

Jim Morey, SUNY Institute of Technology

Gary Scherzer, SUNY Institute of Technology

Hoseoup Lee, SUNY Institute of Technology

Kenneth Wallis, SUNY Institute of Technology

Laura Francis Gladney, SUNY Institute of Technology

\begin{abstract}
Seventy-three New York hospitals were examined to determine if a difference existed between hospitals with nursing unions versus those without as it pertains to fiscal viability and quality of care. Several financial variables were used to construct a fiscal viability index; and a quality index was created from selected mortality and procedural measures that may be used to measure specific aspects of institutional care. The premise that the union status of a hospital's nursing staff will influence fiscal viability and quality is based on the impact that unionization may have on staffing and cost per patient. The literature is replete with studies that assess the relationship between nurse staffing levels and quality. In some cases there is a clear and compelling relationship, but in others, it is indeterminate. Utilizing union status, selected employee variables, and financial and quality of care indices, four statistical models were prepared to explain these the interaction of these variables
\end{abstract}

\section{INTRODUCTION}

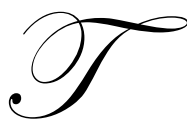

he purpose of this study was to examine what, if any, the impact of union status has on the fiscal viability and quality of hospital care. The relationship, in both cases, is obfuscated by the confounding influence that unionization often brings to a healthcare organization. Unionization doesn't directly influence either quality or financial viability, but has the potential to influence several factors that might, in turn, influence both. The most notable of these influences pertains to nurse-to-patient staffing ratios. Copious research exists on the relationship between nurse staffing levels and quality (Needleman, 2002; Kovner, 2002), and it would stand to reason that unions would seek higher staffing ratios to improve quality and to reduce the burden of low staffing. This is not to say that hospital administrations are unfamiliar with the need to staff properly, but financial factors often encumber their decision making. Staffing comprises a significant proportion of institutional health care costs and if unionization results in higher staffing ratios, without offsetting cost reductions, overall costs will increase.

In general terms fiscal viability and the quality of institutional care are measures that take time to evolve. In this research we make a one year observation, seeking to establish whether a correlation that may have evolved over time, is now manifest. The questions posed by this research are complex, i.e., If union status results in higher nurseto-patient ratios what is the fiscal impact on the organization? What is the impact of higher union wages and benefits on the ability of hospitals to achieve what the literature defines as desirable staffing ratios for quality? And if the staffing levels cannot be achieved, what is the impact on quality? 


\section{METHODOLOGY}

Fiscal viability is an underlying factor that affects every aspect of a health care organization's operations and in previous research by Morey, et al, a fiscal viability index was created (Morey, 2005). For this project, seventy-three hospitals in New York State were chosen. Table 1 shows the variables and ratios utilized in the fiscal viability index.

Table 1: Variables and ratios that determine age of asset and fiscal viability

\begin{tabular}{|c|c|c|}
\hline Variables & Ratio & Formula \\
\hline \multirow{2}{*}{ Fiscal viability from profitability } & (1) Income margin & Net income $\div$ total operating revenue \\
\cline { 2 - 3 } & (2) Return on equity & Net income $\div$ unrestricted net asset \\
\hline $\begin{array}{c}\text { Fiscal viability from capital } \\
\text { structure }\end{array}$ & (3) Equity financing & Unrestricted net asset $\div$ total asset \\
\cline { 2 - 3 } & (4) Cash flow to debt & (Net income + depreciation) $\div$ total liabilities \\
\hline
\end{tabular}

Source: Cleverly, W.O. 1997. Essentials of Health Care Finance, Fourth Edition. An Aspen Publication.

The quality measures employed were selected from among the Inpatient Quality Indicators defined by the Agency for Healthcare Research and Quality (AHRQ, 2007), and were obtained from the Alliance For Quality Health Care website. They are based on data from the New York State Department of Health hospital inpatient database (Alliance, 2004; NYSDOH, 2002). Table 2 presents the Inpatient Quality Indicators, and those used to construct the quality index are in bold. Those used were selected based primarily on their commonality among our study hospitals and whether they had a sufficient number of patients in each category to have their rate reported (Morey, 2005).

Table 2: Inpatient Quality Indicators

1. Mortality Rates for Medical Conditions (7 Indicators)

- $\quad$ Acute myocardial infarction (AMI) (IQI 15)

- $\quad$ AMI, Without Transfer Cases (IQI 32)

- Congestive heart failure (IQI 16)

- $\quad$ Stroke (IQI 17)

- Gastrointestinal hemorrhage (IQI 18)

- Hip fracture (IQI 19)

- Pneumonia (IQI 20)

2. Mortality Rates for Surgical Procedures (8 Indicators)

- $\quad$ Esophageal resection (IQI 8)

- $\quad$ Pancreatic resection (IQI 9)

- Abdominal aortic aneurysm repair (IQI 11)

- Coronary artery bypass graft (IQI 12)

- Percutaneous transluminal coronary angioplasty (IQI 30)

- Carotid endarterectomy (IQI 31)

- Craniotomy (IQI 13)

- $\quad$ Hip replacement (IQI 14)

3. Hospital-level Procedure Utilization Rates (7 Indicators)

- Cesarean section delivery (IQI 21)

- $\quad$ Primary Cesarean delivery (IQI 33)

- Vaginal Birth After Cesarean (VBAC), Uncomplicated (IQI 22)

- $\quad$ VBAC, All (IQI 34)

- Laparoscopic cholecystectomy (IQI 23)

- Incidental appendectomy in the elderly (IQI 24)

- Bi-lateral cardiac catheterization (IQI 25) 
4. Area-level Utilization Rates (4 Indicators)

- $\quad$ Coronary artery bypass graft (IQI 26)

- Percutaneous transluminal coronary angioplasty (IQI 27)

- Hysterectomy (IQI 28)

5. Volume of Procedures (6 Indicators)

- Esophageal resection (IQI 1)

- $\quad$ Pancreatic resection (IQI 2)

- Abdominal aortic aneurysm repair (IQI 4)

- $\quad$ Coronary artery bypass graft (IQI 5)

- Percutaneous transluminal coronary angioplasty (IQI 6)

- $\quad$ Carotid endarterectomy (IQI 7)

Source: Agency for Healthcare Research and Quality. 2006. Inpatient Quality Indicators Overview. AHRQ Rockville, MD.

\section{FINDINGS}

\section{Data Analysis}

Tables 3 and 4 present the descriptive statistics used in this study. 64\% of our sample hospitals are unionized, and the four variables used to ascertain the possible impact of unionization on hospital operations, include: man hours per hospital discharge; FTE per hospital occupied beds; labor costs per FTE; and fringe benefit as a percentage of cost. Unionized hospitals on average use more man hours per discharge (111 vs. 97), more fulltime employees (5.17 vs. 4.84 ), pay higher fringe benefits to its employees ( $20 \%$ vs. $17.7 \%$ ), but incur lower overall labor costs $(\$ 49,547$ vs. $\$ 50,439)$.

Table 3: Descriptive Statistics of Hospital Sample

\begin{tabular}{|c|c|c|c|c|}
\hline Variable & N & Mean & Standard deviation & Median \\
\hline Total fiscal viability index & 73 & 2.32 & 0.89 & 3.00 \\
\hline Quality index & 73 & 1.99 & 0.21 & 2.00 \\
\hline Asset age & 73 & 12.18 & 3.50 & 11.55 \\
\hline Man hours per discharge & 72 & 104.75 & 32.05 & 100.13 \\
\hline FTE per occupied bed & 72 & 5.17 & 1.31 & 4.78 \\
\hline Labor cost per FTE & 72 & $\$ 49,801.00$ & $\$ 5,634.20$ & $\$ 49,239.00$ \\
\hline Fringe benefit as \% of cost & 70 & $18.86 \%$ & $4.41 \%$ & $19.05 \%$ \\
\hline
\end{tabular}

*On a scale from $1-3$.

Source: IRS Form 990 - 2002; and TreoSolutions. 2007. Financial and Operations Management, 2002.

The sample size for man hours, FTE per occupied bed, labor cost per FTE, and fringe benefits as a percent of cost is slightly smaller than the number of hospitals reporting nurse union status due to difficulty acquiring these data from all hospitals.

Table 4: Descriptive Statistics of Hospital Sample by Union Status

\begin{tabular}{|c|c|c|c|c|c|c|c|c|}
\hline \multirow{3}{*}{ Variable } & \multicolumn{8}{|c|}{ Union Status } \\
\hline & \multicolumn{4}{|c|}{ Unionized } & \multicolumn{4}{|c|}{ Non-unionized } \\
\hline & $\mathbf{N}$ & Mean & $\begin{array}{l}\text { Standard } \\
\text { deviation }\end{array}$ & Median & $\mathbf{N}$ & Mean & $\begin{array}{l}\text { Standard } \\
\text { deviation }\end{array}$ & Median \\
\hline Man hours per discharge & 43 & 110.94 & 36.49 & 100.78 & 25 & 96.69 & 22.57 & 99.4 \\
\hline FTE per occupied bed & 43 & 5.17 & 1.36 & 4.78 & 25 & 4.84 & 1.22 & 4.77 \\
\hline Labor cost per FTE & 43 & $\$ 49,547$ & $\$ 5,489$ & $\$ 48,517$ & 25 & $\$ 50,439$ & $\$ 6,270$ & $\$ 49,941$ \\
\hline Fringe benefit as $\%$ of cost & 42 & $20.02 \%$ & $3.44 \%$ & $20.33 \%$ & 24 & $17.70 \%$ & $3.86 \%$ & $17.07 \%$ \\
\hline
\end{tabular}




\section{Analysis Of Results}

This section presents the analysis of variables collected in this study in the form of four analytical models:

Model 1: Effect of Nurse Unionization on Fiscal Viability Index

Model 2: Effect of Nurse Unionization, Asset Age \& Quality of Hospital Care on Fiscal Viability Index

Model 3: Effect of Nurse Unionization on Quality of Hospital Care

Model 4: Effect of Nurse Unionization, Hospital Staffing \& Labor Costs on Quality of Hospital Care

Model 1: Effect of Nurse Unionization on Fiscal Viability Index $(N=69)$

\begin{tabular}{|c|c|c|}
\hline Variable & Coefficient & t-value \\
\hline Intercept & 2.52 & $14.02 * * *$ \\
\hline Nurse unionization & -0.36 & -1.60 \\
\hline R-square & \multicolumn{2}{|c|}{$2.26 \%$} \\
\hline F-value & \multicolumn{2}{|c|}{2.57} \\
\hline
\end{tabular}

Significance level: $* * *(1 \%)$

***Implication - Although this model is not statistically significant, the result indicates that nurse unionization impacts negatively on the fiscal viability of hospitals. In other words, unionized facilities are less financially viable than non-unionized facilities.

Model 2: Effect of Nurse Unionization, Asset Age \& Quality of Hospital Care on Fiscal Viability Index $(\mathrm{N}=69)$

\begin{tabular}{|c|c|c|}
\hline Variable & Coefficient & t-value \\
\hline Intercept & 1.50 & 1.40 \\
\hline Nurse unionization & -0.18 & -0.83 \\
\hline Asset age & -0.09 & $-2.81^{* * *}$ \\
\hline Quality of care & 0.98 & $1.88 *$ \\
\hline R-square & \multicolumn{2}{|c|}{$12.40 \%$} \\
\hline F-value & \multicolumn{2}{|c|}{$4.21 * * *$} \\
\hline
\end{tabular}

Significance level: $* * *(1 \%) ; *(10 \%)$

***Implication - Compared to Model 1, with the introduction of age of asset and quality of hospital care, the negative impact of nurse unionization on a hospital's fiscal viability decreases from -0.36 to -0.18 . This means that if a hospital has higher quality and newer assets, the hospital can absorb most of the negative financial effect of nurse unionization. As expected, the negative effect of asset age and positive impact of quality care on fiscal viability are statistically significant.

Model 3: Effect of Nurse Unionization on Quality of Hospital Care ( $=69)$

\begin{tabular}{|c|c|c|}
\hline Variable & Coefficient & t-value \\
\hline Intercept & 2.04 & $50.43 * * *$ \\
\hline Nurse unionization & -0.09 & $-1.79 *$ \\
\hline R-square & \multicolumn{2}{|c|}{$3.14 \%$} \\
\hline F-value & \multicolumn{2}{|c|}{$3.20 *$} \\
\hline
\end{tabular}

Significance level: $* * *(1 \%) ; *(10 \%)$

***Implication - This result indicates that hospitals with unionized nurses tend to provide less quality patient care, statistically significant at less than the $10 \%$ level. Staffing shortages in unionized hospitals may contribute to lower quality of patient care. 
Model 4: Effect of Nurse Unionization, Hospital Staffing and Labor Costs on Quality of Hospital Care (N= 65)

\begin{tabular}{|c|c|c|}
\hline Variable & Coefficient & t-value \\
\hline Intercept & 1.74 & $6.12 * * *$ \\
\hline Nurse unionization & -0.04 & -0.78 \\
\hline Man hours per hospital discharge & -0.00 & -1.33 \\
\hline FTE per hospital occupied beds & 0.05 & $2.04 * *$ \\
\hline Labor cost per FTE & 0.00 & $2.13 * *$ \\
\hline Fringe benefit as \% of cost & -0.01 & $-2.15 * *$ \\
\hline R-square & & $16.59 \%$ \\
\hline F-value & \multicolumn{2}{|c|}{$3.59 * * *$} \\
\hline
\end{tabular}

Significance level: $* * *(1 \%) ; * *(5 \%)$

***Implication - Compared to Model 3, the significant negative impact of unionization on hospital quality is reduced at least by half $(-0.091$ to -0.042$)$, and becomes statistically insignificant with the introduction of man hours per discharge, FTE per occupied bed, and labor cost variables into the analysis. Nurse unionization itself does not have as much of an effect on hospital quality when the four additional variables are considered. Overall goodness of fit (adjusted R square) indicates that variables in this model explain more than $16 \%$ of hospital quality, a significant increase from Model 3 (3.14\%). The level of FTE staffing per occupied bed becomes the most dominant factor for hospital quality. This means that the greater the staffing in a hospital, the less impact nurse unionization has on hospital quality. A higher level of FTE, regardless of union status, improves hospital quality.

The negative effect of man hours per hospital discharge on quality is statistically insignificant, and this is most likely due to the high correlation between man hours and FTE variables.

The effect of labor cost on quality is statistically significant, but its relative magnitude is negligible.

According to our analysis in Model 4, fringe benefits as a percentage of cost, has a negative and statistically significant effect on hospital quality. With the relatively high costs associated with providing fringe benefits to employees, hospitals may rely more on part-time employees than full-time. The frequency of staff turnovers with part-time employees may also impact quality negatively.

\section{CONCLUSIONS AND FINDINGS}

Numerous factors influence the financial viability and quality of care in a hospital, and it is difficult to specifically correlate union status with fiscal viability and quality. However, the evidence is compelling that the fiscal health of an organization will directly affect the outcomes of hospital care. That being said, union status has significant implications as it pertains to hospital operations. Ultimately the question that needs to be addressed is can hospitals "afford" the effect of unionization and do they have a choice. The key findings of this research are:

- Unionization by nurses has a negative impact on fiscal viability when analyzed on a cause and effect basis.

- When age of assets and quality are added to the analysis the impact of unionization on quality diminishes.

- When hospitals with unions are analyzed for quality, there is statistically significant lower quality.

- $\quad$ The impact of unionized nursing on quality is reduced by half when man hours and FTEs per occupied bed are included in the analysis; and the effect of FTE per occupied bed becomes the most dominant factor. Quality increases with increases in FTE per occupied bed.

- $\quad$ Staffing, regardless of union status is the most significant factor in quality.

- $\quad$ Labor cost per employee is not a significant factor on quality.

In conclusion, unions per se have no direct affect on financial viability or quality; but have significant indirect affects. These findings have important implications for policy makers and hospital administrators when planning to engage unions in salary negotiations and staffing levels. 


\section{REFERENCES}

1. Agency for Healthcare Research and Quality. (2006). Inpatient Quality Indicators Overview. AHRQ Rockville, MD. Retrieved from: http://www.qualityindicators.ahrq.gov/iqi_overview.htm.

2. Alliance For Quality Health Care (Niagara Health Quality Coalition.). (2004) Indicators of Inpatient Care in New York Hospitals. Retrieved from: www.myhealthfinder.com.

3. Cleverly, WO. (1997). Essentials of Health Care Finance, Fourth Edition. An Aspen Publication.

4. IRS Form 990 for year 2002. Retrieved from: www.Guidestar.org.

5. Kovner, C, Jones, C. et al. (2002). Nurse Staffing and Postsurgical Adverse Events: An Analysis of Administrative Data from a Sample of U.S. Hospitals, 1990-1996. Health Services Research, Vol. 37, No. 3 (June), $611-629$.

6. Morey, J, Scherzer, G and Lee, H. 2005. Impact Of Asset Age/Fiscal Viability On Selected Measures Of Quality In Hospitals. Journal of Business and Economics Research, 3 (11), 69-76.

7. Needleman, JN, Buerhaus, P, et al. (2002). Nurse-Staffing Levels and the Quality of Care in Hospitals. New England Journal of Medicine, Vol. 346, No. 22 (May), 1715-1722.

8. New York State Department of Health. (2002). Statewide Planning and Research Cooperative System. Hospital Inpatient Data of New York State.

9. TreoSolutions. (2007). Financial and Operations Management, 2002. Retrieved from www.treosolutions.com.

\section{NOTES}

